\title{
Irish researchers divided over how to spend huge new fund
}

\section{Munich}

In a remarkable reversal of fortune, Ireland's spending on basic research is set to increase by more than an order of magnitude. A new foundation is to be created to administer the money. But scientists are divided over plans for how the foundation will spend the windfall.

Around half of a new $\mathrm{I} £ 1.95$ billion (US\$2.5 billion) fund for research, technology and innovation in Ireland's six-year National Development Plan should feed directly into basic research. Researchers in biotechnology and information technologies will gain most, receiving I£560 million.

A further $I £ 550$ million is expected to be allocated by the Higher Education Authority to support research in universities across all disciplines. The goal is to create a 'knowledge base' to support the high-tech companies that have recently settled in Ireland, and to lure the country's scientific diaspora home.

Science minister Noel Treacy boasts that the initiative will bring a "sea change of attitude" in a country that has long languished near the foot of Europe's league table for spending on research.

The foundation will fund biotechnology and information technology projects using international peer review. More controversially, Treacy says it will also "have the option to establish its own laboratories if necessary, to secure world-class performance".

Many scientists are deeply unhappy with the idea of investing in bricks and mortar. They point out that Ireland has recently invested heavily in its university infrastructure from a special $I £ 210$ million fund that was set up last year.

"Monolithic, stand-alone institutes very easily turn into white elephants," warns Mark Keane, professor of computer science

\section{Protests force primate farm to close}

London

Britain's only supplier of primates for research has been forced to shut down after a campaign by animal-rights activists.

Primates are not bred for research in Britain. Shamrock Farm in West Sussex imported them from breeders in countries such as Mauritius and the Philippines, then sent them to laboratories. Once its remaining animals have been distributed to scientists, the facility will close.

In recent months, Shamrock Farm has seen confrontations between masked

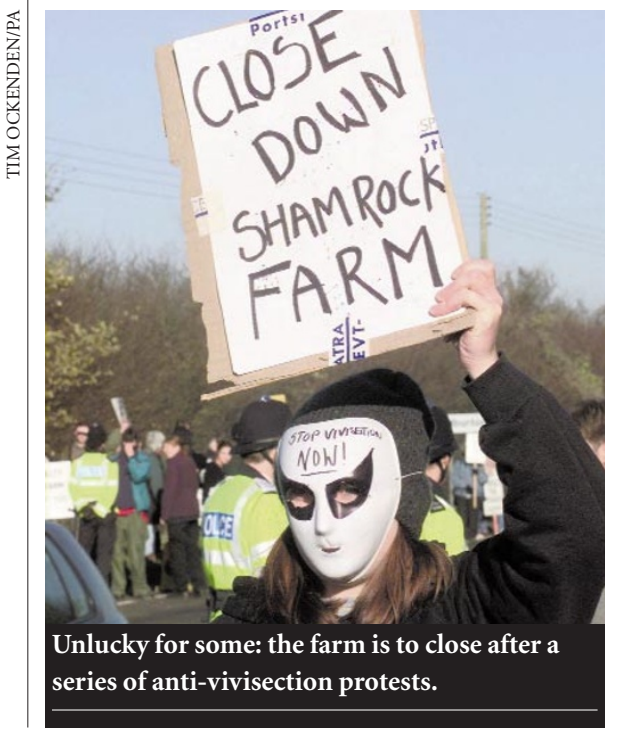

protesters and police. The farm's managing director has suffered a series of attacks; most recently someone broke into her garage and set fire to her cars.

A total of 3,098 primates - most of them macaques - were used for research in Britain in 1998, the last year for which figures are available. More than half came directly from suppliers overseas. The closure of Shamrock Farm means that all primates used by British labs will in future be supplied in this way.

Shamrock Farm is the latest in a line of British suppliers of research animals forced to close after being targeted by animal rights activists. In 1997, Consort Kennels of Rosson-Wye, a breeder of beagles, closed after a concerted campaign during which it was besieged by thousands of activists, its perimeter fence was breached and directors' homes were attacked. Last year, Hillgrove Farm in Witney near Oxford closed after letter bombs were sent to the farm's owner, Christopher Brown, and two employees.

"It's very clear that the activists will now go and target other animal breeders," says Mark Matfield, director of the Research Defence Society. "It's a worrying trend."

Since the Home Office regulates animal experimentation and oversees the Crown Prosecution Service and the police, says Matfield, its ministers could easily order a crackdown on activists. The Home Office was not available for comment. Peter Aldhous

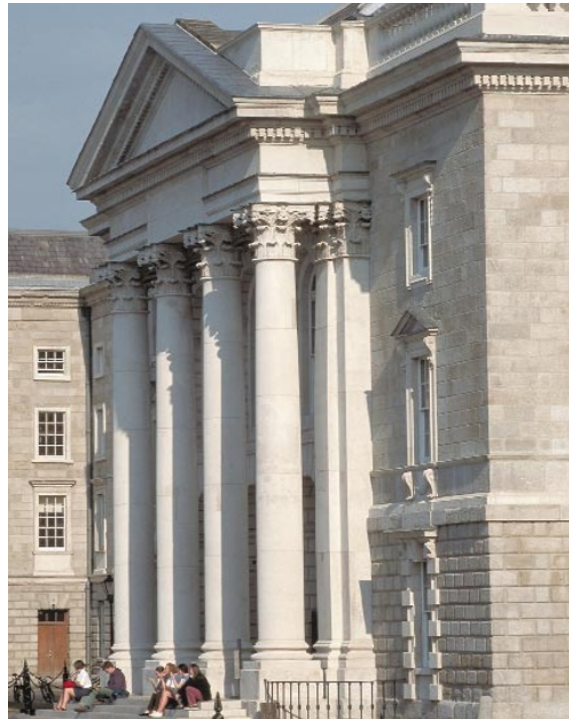

Academic question: should new money go to established centres such as Trinity College?

at University College Dublin. "In the past, there has been a huge amount of unsupported talent in Irish universities: now is the time to support people, not places.'

Many believe the money should be used for project grants and to create prestigious positions to entice the best researchers to Ireland. There is also some disquiet about the fact that the government has already allocat-

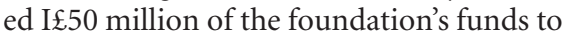
support the Massachusetts Institute of Technology's Media Lab Europe, recently established in Dublin.

"When a government commits to increase research spending by one to two orders of magnitude then of course we should be celebrating and not arguing too much about the details," says David McConnell, director of the Smurfit Institute of Genetics at Trinity College Dublin. Only two years ago, Irish researchers were facing a situation in which their budget for projects could be wiped out at a moment's notice (see Nature 392, 529; 1998). But McConnell too, believes that the greater part of the new money would best be deployed in Ireland's existing universities.

The government likes the idea of independent institutes because they would give the initiative highly focused visibility. Frank Gannon, head of the European Molecular Biology Organization and formerly a professor at the University of Galway, says that a new, well-funded institute would be "very likely to develop a high-quality research ethos in Ireland".

Gannon is a member of the group that will help decide the new foundation's structure. Other members of this group are less enthusiastic about creating new institutes. They need to resolve their differences quickly, however. For accounting reasons, I $£ 25$ million of the foundation's funds must be spent before the end of the year. Alison Abbott 